\title{
Familicide from a clinical-community psychology perspective
}

\author{
J.W. Pretorius-Heuchert \\ Department of Psychology \\ Potchefstroom University for $\mathrm{CHE}$ \\ POTCHEFSTROOM
}

\begin{abstract}
In this article familicide and homicide-suicide acts in South Africa and elsewhere are discussed. Issues that are considered include the following: the definition of familicide, the incidence of cases, population groups involved, the role of suicide, the role of psychopathology, familial versus nonfamilial murderers, the influence of stress, male propriefariness in combination with an exaggerated sense of responsibility, age and gender, and sociopolitical influences. An attempr is made to integrate the personal and societal factors of familicide from a clinical-community psychology perspective, relying specifically on the theories of Frantz Fanon and Hussein Bulhan. It is proposed that an understanding of the oppressor-oppressed relationship, as well as threats to that relationship, may shed light on the current high rate of familicide that occurs mostly among white Afrikaner, South African males, and their families.
\end{abstract}

\section{INTRODUCTION}

The world has known of homicide-suicide acts in the family for many centuries: family murders were recorded as early as the Ming dynasty and in the time of Greek mythology (Berman, 1979:15). Familicide (as intrafamilial homicide-suicide) however, remains a perplexing phenomenon and has been part of South African life for at least the past 20 years. Early information on incidents of familicide in South Africa has mostly been gained from newspaper reports. As recently as 1978 the first academic article on the matter was published (Pienaar, 1978). Pienaar refers to a particularly horrific familicide in 1977 and states that familicide has become quite common. It seems as if the increase in familicide coincided with the intensification of the political uprising since 1976. As this paper will assume a clinical-community psychology perspective, the link between the psychological characteristics of individuals who commit familicide. and their socio-psychological environment will be an important focus.

\section{THE CONCEPT OF FAMILICIDE IN INTERNATIONAL CONTEXT}

The phenomenon of familicide seems to occur in varying degrees, and for various 
reasons in several countries around the world. Allen (1983:156) reports on several instances of homicide followed by suicide in the United States of America, and also reports that according to West homicide-suicide rates are high in Denmark, England, Wales and Australia. Iga $e t$ al. (1978) report high frequencies of homicide-suicides between parents and children in Japan. It seems then, that instances similar to the South African type of familicide are indicated, but that they differ in that they often manifest in familicide between adults (USA) or between the mother and child(ren) (Japan). Ishikawa (1989:2) states that in the Japanese language one can differentiate between five different types of suicide. Furthermore it is stated that there are several characteristics of the Japanese society that may shed light on the phenomenon of oyako shinju (parent-child suicide) which occurs at a rate of up to 500 cases per year (Berman, 1979:22). The characteristics of Japanese society include the following aspects:

- The children are considered to be the parent's creation, and the parent can decide to take the children's life in order to protect them from potential harm, such as facing life without parents, if the parents should decide to commit suicide.

- Parents have a duty to take care of their children, and by committing oyako shinju, they reason that 'they have fulfilled their responsibility to their children and do not have to feel any guilt'.

- The Japanese perceive death as attractive, and as a purification of previous mistakes.

- In Japan no strong societal or religious taboos against oyako shinju exist.

- The Japanese consider life as full of suffering and parents can release their children from this (Ishikawa, 1989:3).

This sense of responsibility and proprietariness characteristic of Japanese society will also be considered in the South African context.

\section{FAMILICIDE AS DEFINED BY SOUTH AFRICAN RESEARCHERS}

There seems to be consensus that familicide is the situation when a parent kills one or more of the children, often the other spouse and then commits, or attempts to commit suicide (Du Toit, 1988; De Jong van Arkel, 1985; Graser, 1987; Pretorius, 1987; and others). Several authors state that familicide is actually an extension of suicide (Du Toit, 1988; De Jongh van Arkel, 1985; Berman, 1979, and others). This phenomenon 
is perceived in cases where a parent decides to commit suicide, and then kills the other members of the family because the parent feels responsible for them and 'releases' them from this world, or because the parent thinks he/she has the right to do it as head of the family. Moolman (1988:10) reports the statement of a person who had planned a familicide (that was not carried out). The person said that the parents could not continue with life, and that they 'knew' that the children would not cope. These parents worried about the fact that the children would be left alone, and then decided to 'take them with them'. This distorted sense of responsibility for the children was also reported by Roos, Haasbroek and Marchetti (1992).

Olivier et al. (1991) offer a somewhat idiosyncratic definition of familicide. Their inclusion of the mere intent to commit familicide, and the exclusion of the suicidal aspect of familicide, may lead to a confusion of familicide with familial homicide. Familicide may also be confused with a different phenomenon, namely the fantasy of familicide (intention to commit familicide). Clinicians know that a very small percentage of people with thoughts about suicide eventually attempt suicide and that the thought and talk of suicide often serve a very different purpose for the person and may not mean that an attempt is imminent. In the same way the consideration of familicide cannot be equated with the act of familicide. For the purpose of this paper then, the essential elements of familicide are the following:

- the murder of a family member (spouse or child/children) by a parent;

- the murder, or intention to murder the other members of the family;

- the suicide, or a suicide attempt, or the intention to commit suicide.

\section{ELEMENTS OF FAMII JCIDE PERTINENT TO THIS PAPER}

\subsection{Incidence of familicide cases}

Several estimates of the incidence of familicide in South Africa have been ventured, but no definitive study has been done. Graser (1987:264) reports that there were 10 incidents of familicide in 1983, 13 in 1984, and 17 in 1985. Stander (1988:5) reports that the numbers had increased to 27 in 1986, and to 50 in 1987. Du Toit (1988) found newspaper reports of 21 cases in a seven year period. He later warned that these reports might be a gross underestimate, as police reports indicated that 40 familicides occurred in 1988, while only 13 were reported in the newspapers in that year (Du Toit, 1990). The most reliable estimate to date is probably the above mentioned report from the Bureau for Statistics quoted by Du Toit (1990). The study of cases done by 
Olivier $e$ al. (1991) indicates that at least 12 familicides (by their definition) took place between April 1989 and October 1990. They set out to find 12 cases ( 3 cases of white South Africans, and 9 cases from other groups), and did not report the total number of cases that occurred in that period. In the survey part of their study they found that their respondents (psychologists, social workers, physicians, etc.) encountered 724 cases in the five years prior to 1989. In addition to these two sections of their study, Olivier et al. (1991) also report the 40 cases of which the particulars had been provided by the police as Du Toit did earlier. According to the police records, another five cases of familicide took place in January 1989 (Olivier et al., 1991). These police figures of 40 familicides for 1988, reflect that familicide occurred at a rate of 0,13 per 100000 people in South Africa.

Murder, followed by the offender's suicide, is the topic of Palmer and Humphrey's (1980) study. This type of murder is the closest analogy to the South African type (family murder, or extended suicide) that could be found in international literature. It is reported that the whites-only homicide-suicide rates in the United States were 0,16 per 100000 in North Carolina and 0,19 per 100000 in Philadelphia. They also quote the statistics that West reported for England and Wales (in 1966), and these statistics represent 0,16 per 100000 white homicide-suicide offenders (107). Coid (1983:856) reports an average of 0,18 for all the groups used in his study. The results of Palmer and Humphreys' (1980) study suggest that homicide-suicide offenders are in most respects more similar to suicide-only individuals than homicide-only individuals. They conclude that for homicide-suicide individuals, the killing of a family member seems to be a part of the evolving process of suicide (117).

\subsubsection{The South African societal group most likely to commit familicide}

Authors on familicide in South Africa agree that, based on their investigations, familicide in South Africa is overwhelmingly a white South African phenomenon. Graser (1987:264) reports that 38 of the 40 cases he studied occurred in white families, Du Toit (1988) reports that of the 21 cases he studied, all were white, and of the 40 cases that the police identified in 1988, 27 were white (Olivier et al., 1991). Despite the fact that Olivier $e t$ al. intended to use only three white and nine other cases, they ended up with seven white and four other cases, again almost twice as many whites, despite their (Olivier et al.'s) stated effort to the contrary. The 21 cases identified by respondents to their survey were all white (252), despite the fact that the research team sent out hundreds of survey cards to black school principals, social workers and other professionals.

If one accepts the police report mentioned earlier as the best source, then one finds 
that familicide in South Africa, for that given period, manifested itself at a rate of 0,54 per 100000 white South Africans. Among the other groups the rate was 0,052 per 100000 . A different way of putting this startling fact is that the familicide rate was more than 10 times higher among white South Africans, than among the other South African population groups.

\subsubsection{Differences between Afrikaans- and English-speaking whites in terms of} familicide rates

Almost all the reports on familicide in South Africa have stated that there are significantly more cases of Afrikaner whites who commit familicide (Graser, 1987:264; Du Toit, 1990:289; Stander, 1988:5 and others). Olivier et al. (1991:285) report that in their survey, $76 \%$ of the familicide offenders were Afrikaners.

\subsection{Familicide and the role of suicide and fatalism}

Suicide seems to be intimately connected to familicide and several authors state that familicide usually includes the offender's suicide, or suicidal intent (Graser, 1987:263; De Jongh van Arkel, 1985:140; Pretorius, 1987:136; Du Toit, 1990:287 and others). Olivier et al. (1991:249) report that all 21 familicide cases that were identified in their survey, involved a suicide attempt by the offender.

Peck (1980:8) explored the empirical relationship between suicide and fatalism. His findings revealed that there was a strong correlation between suicide and fatalistic thought patterns and social conditions. Peck, in his study of 132 suicides, also reports that slightly more "fatalistic suicides" occurred among Protestants in the USA. Afrikaans-speaking whites are generally Protestants, and if one can generalize from Peck's study, one would expect a higher degree of fatalism among Afrikaners. This degree of fatalism may lead to individuals feeling powerless to bring about change in their lives, and feeling a lack of control over the social environment. De Jong van Arkel (1985:143) suggests that the reason for higher suicide rates (as reported by Emile Durkheim) among Protestants may be that the Protestant religion has less structure and may be less supportive to people in need. It is further stated that fatalism may also develop, or increase, under conditions of extreme stress (as found in South Africa), and may lead to desperation. This desperation, together with fatalistic feelings of powerlessness regarding the future, may then lead to suicide, or family murder as a form of suicide. These feelings of fatalism may be particularly intense during the long periods of political unrest, and the realization of the inevitability of change in South Africa. When strong values (such as those that exist among white 
South Africans) become threatened, and a decrease in the standard of living seems imminent, suicide (and familicide) may follow, as Iga et al. (1978) indicate.

Olivier et al., (1991:253), report that $71 \%$ of their survey group was Protestant. De Jongh van Arkel (1985:144) states that Protestants are more likely to experience feelings of helplessness, and deduces that familicide offenders feel more hopeless, and are therefore more likely to feel suicidal (with the implications for familicide as mentioned before).

Feelings of desperation and hopelessness may go hand in hand with fatalism, and Olivier $e$ al. (1991:20) report that hopelessness is a significantly better indicator of suicidality than depression - a fact which is proved by the results of their survey (104). Peterson (1985:171) reports that death anxiety also leads to 'estrangement' from the outside world, making suicide more likely.

\subsection{The role of psychopathology in familicide}

The presence or absence of psychopathology in familicide offenders and in the society in which familicide occurs, has been addressed by several authors. Graser (1987:266) focuses on the pressure of depression, as do Du Toit (1990:291), Rosenbaum (1990:1038) and Fishbain (1986:1319), but Lester (1986:930) found nonsignificant correlations for depression scores and suicide rates in eight countries. Other authors (McCully, 1978; Peck, 1980) have attempted to establish the psychodynamic intricacies of homicide and suicide offenders. Pretorius (1987:137) discusses general psychopathology in the familicide offender.

The presence or absence of psychopathology should, however, be seen in the context of a society that has been found to have an elevated base-line of psychopathology, as reported by Lambley (1980), Van der Spuy et al. (1978), Duckitt (1985), Dawes (1985), Crapanzano (1985), Bekker (1986), Domisse (1983), Seedat (1984) and Olivier (1988:117). The findings of higher levels of psychopathology among white South Africans than among people from other countries, have been replicated and discussed previously (Pretorius, 1989a). It is suggested that familicide may be another behavioural outcome of this elevated level of general psychopathology among white South Africans (Pretorius, 1989b:12). It should be borne in mind, however, that Perdue and Lester's (1973) and Allen's (1983:164) findings indicate that familial murderers have less obvious pathology. This seems to hold true for South African familicide offenders, who are generally described as relatively quiet, usually leading lives that do not direct the kind of attention to them that one would have expected of someone contemplating such a serious act. 
Du Toit (1990:291) points out that even if the presence of psychopathology is established in familicide offenders, the particular behavioural expression (that is, familicide) is not explained.

In an earlier paper (Pretorius, 1991) an attempt was made to integrate the results of a study on aspects of white South African identity development with psychopathology, as reflected in the Hopkins Symptom Checklist-80 (HSCL-80) (Lipman et al., 1979). It is reported that the total sample of white South Africans $(N=849)$ had significantly $(p$ $<0.001)$ higher scores on all symptom distress factors for which United States normative data are available. The South African subjects also reported higher symptom scores on every item than did the comparison group. In addition, there was a significant difference in symptom scores between Afrikaans- and English-speaking whites, with Afrikaners scoring higher on eight out of ten subscales, as well as on the total score. Among others, Afrikaners also had significant higher mean conservatism scores, Belief-in-a-Just-World (BJW) scores and higher scores on the Social Distance from English Whites scale, as well as higher scores on the Social Distance from Black South Africans Scale. A small, but significant positive correlation between symptom scores and Social Distance, Anomie and BJW scores were found. Symptom totals did not have a strong correlation with any of the white racial identity measure (Helms, 1990) subscales, but there is a pattern that indicates a consistent change in the correlations from a small positive correlation in the first stages of racial identity development, to a small negative correlation in the later stages. This pattern suggests a - decrease in symptom scores, as people become more autonomous and tolerant in their racial identity, as indicated by higher scores on the later stages of racial identity development.

The multitude of personality and psychopathology characteristics that have been suggested are largely uninterpretable in terms of finding one or a small number of 'causes' and are often mutually exclusive. For example, the personality disorder 'tendencies' found by Olivier et al. (1991:271) cover nine of the eleven personality disorders recognized by the DSM-III-R (APA, 1987). The other symptoms (201) that are mentioned are also quite common, (for example, irritability, lack of assertiveness, incongruent behaviour, etc.), yet most people do not commit familicide. The common denominators of group membership and group characteristics, as well as sociopolitical factors rather than individual differences may be more useful in trying to understand and prevent this phenomenon.

\subsection{Familial vs. nonfamilial murderers}

Perdue and Lester (1973) found that people who killed relatives showed significant 
psychological differences compared to people who killed unrelated victims. It is suggested that familial murderers may have increased emotional sensitivity, less need for physical activity, and lowered depression and anxiety. It is concluded that this may be due to a catharsis experienced as a result of the murder, or that the familial murderer may have had less psychopathology before committing the murder. These people may then be those one would 'least expect' to commit murder, as is often said about the offender, by survivors or acquaintances. Alternatively, the murder (and perhaps subsequent suicide) is experienced as a relief.

Kratcoski (1988:66) states that familial murders are more likely to be spontaneous, sometimes following upon a family quarrel. In contrast, Moolman (1988:10) reports that people planning familicide may make their preparations waiting for an 'excuse', such as a family quarrel, or problems other family members may be experiencing (such as a serious illness) to commit the deed. Selkin (1976:82) confirms this in a study of 13 homicide-suicide offenders and states that "in every instance the event was preplanned". Holinger and Klemen (1982:1937) state that homicide and suicide offenders may have a common intrapsychic etiological factor of an unconscious self-destructive tendency that may find behavioural expression in homicide and suicide. Familicide may then be seen as a clear example of the intent to destroy oneself, and the destruction of others may be part of this process.

\subsection{The influence of stress}

Olivier et al.(1991:275) report that in most of the case studies family murderers experienced high levels of stress. Male murderers were found to have higher stress scores than females, and white males with high stress scores were more likely to kill family members than nonwhite males (Kratcoski, 1987). Women who killed an adult family member, also had high stress levels, strong feelings of helplessness, and were more likely to kill in self-defence after long periods of abuse.

Humphrey and Palmer (1980) studied stressful life events experienced by homicide offenders and found that they experienced stressful life events more intensively and more consistently than nonviolent offenders. In addition they found that murderers who killed family members or close friends were more likely to have experienced stressful life events involving early loss (Humphrey \& Palmer, 1980:118). Nonfamilial murderers experienced more non-loss stressful life events. It is concluded that the data suggest that homicide offenders may be responding to chronic stress (like that existing in South Africa), while nonviolent offenders may be responding to acute stress (Humphrey \& Palmer, 1987:306). It is suggested that homicide may be one of the behavioural outcomes of stress. 
The stress research seems particularly relevant to the South African context. The studies of Kratcoski (1987) and Humphrey and Palmer $(1980,1987)$ indicate that familial murder is related to stress experienced. It is also stated that individuals are differentially affected by stress. Based on these findings it can be expected that the chronic stress associated with living in South Africa may increase the likelihood that white males over thirty may be more susceptible to family murder. Stress resulting from losses is also related to familial murder, and this jeopardizes South Africans as the high suicide rates, homicide rates, the continuous political unrest, high levels of alcohol related deaths (e.g. road accidents), increase the likelihood of more people experiencing more losses. Marriot and Fitzgerald (1981:114) state that stress reactions are closely related to significant cultural and political events, and alteration in behaviour can be expected during these times. It should be kept in mind, though, that South Africans other than whites, have many more stressors, yet they do not resort to familicide as readily. Perhaps the nature of the stressors is different, or the hope for solutions to sociopolitical problems is viewed differently.

\subsection{Male proprietariness and a distorted sense of responsibility}

Daly and Wilson (1988) propose that genetic relationships should serve as a preventative factor against familial murder (in an evolutionary context). They conclude that most familial homicides are spousal homicides (no genetic relationship) and suggest that it is due to male proprietariness, which is also the conclusion drawn by Devasia and Devasia (1984:322), Visser (1990:21) and Palmer and Humphrey (1980).

The studies proposing male proprietariness as a factor in familial murder are of particular significance in the South African context, as white South African fathers are reportedly very dominating, and tend to see their wife and children as property, resulting in an exaggerated sense of responsibility (Visser, 1990:21; Stander, 1988:5; De Jongh van Arkel, 1985:145). This characteristic may lead to an inability to see wife and children as independent, responsible and effective beings. Consequently these fathers feel at liberty, and may even feel it to be their duty and responsibility, to kill the family, when suicide is contemplated.

\subsection{Age and gender}

Palmer and Humphrey (1980:115) report that, in the United States, white males over 30 years of age were more likely to be involved in interspousal homicide-suicide incidents, than in homicides alone. In England and Wales, a higher proportion of females was involved in homicide-suicide cases, and they tended to kill their own 
children, rather than a spouse (West, 1966, in Palmer and Humphrey, 1980:117).

Males over the age of thirty have also been identified as being more likely to be perpetrators of homicide-suicide acts (Allen, 1983:157; Rosenbaum, 1990:1037, and Berman, 1979:17). The mean age of the people in Olivier et al.'s (1991:131) eleven case studies was almost 34 , and eight of these people were males.

\section{INTEGRATION FROM A CLINICAL-COMMUNITY PSYCHOLOGY PERSPECTIVE}

Clinical-community psychology attempts to integrate the intra-personal with the interpersonal and societal aspects of people's lives. In this paper an attempt was made to highlight some of the more salient aspects of the familicide offender's psyche. A myriad of etiological factors have been referred to by other authors ranging from sexual incompatibility (Graser, 1987:267) to child-rearing practices (Lester, 1980:682). But, with the notable exception of Du Toit $(1988,1990)$ and a few others, the sociopolitical reality of white South African life has not been addressed adequately. Olivier et al. (1991:49) discuss the necessity of taking the 'social reality' into account, but judging by their report, they addressed sociopolitical issues very briefly. In their 63 page questionnaire three questions regarding matters which can generally be regarded as party political matters had been asked (out of approximately 1500 questions or statements that had to be responded to).

The increase in familicide seems to have corresponded with the increase in political unrest in South Africa since 1976 (Pretorius, 1987:140). The theories of the psychology of oppression as proposed by Fanon (1968), and interpreted and expanded upon by Bulhan (1985), may provide the link between these two events. Briefly, the theory focuses on the relationship between oppressors and the oppressed. It is stated that this relationship is established because of people's inherent need for recognition in the eyes of others. When two people meet, both want recognition, but neither wants to recognize the other, and this leads to confrontation. This confrontation is resolved as one person (who is determined to force recognition, even at the risk of death), becomes recognized by the other (who is determined to live, even for the moment, as an oppressed person). Alternatively, if both are determined to risk their lives, a struggle may ensue, with someone dying, or becoming overpowered. Fanon focuses particularly on the aftermath of the establishment of this relationship, and particularly from the oppressed's point of view. But, the oppressor is left in the peculiar position that is also the historical dilemma of a colonizer. It is the tragic (in its self-destructive sense) flaw built into the character of an oppressor, in terms of Hegel's master-slave dialectic (as discussed by Bulhan, 1985). The dilemma is that the oppressor's original need for 
recognition is obtained by subjugation, and is lost when it is realized that obedience may be enforced, but not recognition. In addition, there is the problem of being (obediently) recognized by dehumanized beings, which is not authentic recognition. The oppressor's feelings of inferiority re-emerges when it has to be admitted that the grand scheme has failed. In addition to this the oppressor receives the devastating news that resentment, fury and rejection will be the reward for a life time of 'devoted labour' to maintain the system he believes in, as the best for all. Bulhan goes on to say that the oppressors find themselves in an 'existential rut' from which they have difficulty to escape. Having experienced being masters (oppressors), having tasted power, having accepted mastery as the only and ultimate value, the oppressor, confronted by impending dethronement, can only escape via one route: death. In the case of familicide, the patriarchal master exerts a final show of power over the family before dying.

Fanon (1968) discusses the various forms of violence that result from the stresses suffered in situations of oppression. He discusses the direct and indirect violence of an oppressive system and also what he terms the "collective autodestruction" (54) so prevalent in minority societies. This violence against the self, one's own family, and community, is usually the result of an inability to strike back at a violent system or a system that is beyond one's control, and usually takes the form of drug abuse, alcoholism, crime, delinquency, family violence, child abuse, suicide or homicide.

- Although white South Africans are currently in power, they are numerically a minority and experience their society as being under siege. They certainly have many of the psychological characteristics of a minority group, including the "collective autodestruction", mentioned by Fanon, as evidenced by the high rates of familicide, alcoholism, suicide, and other forms of destroying one's life. They do not bear the brunt of an oppressive system, but do pay a psychological price of constant fear, anxiety, guilt and uncertainty.

Du Toit (1988) very cautiously links the occurrence of familicide with the racial policies in South Africa. He proposes that white South Africans assume responsibility for black South Africans (as parents do for their children, and in the exaggerated sense familicide offenders do for their children), through self-imposed 'determination right' (beskikkingsreg), meaning the right to determine the lives of black South Africans, as parents would the lives of their children. Consequently a responsibility to take care of their self-imposed and unwilling charges follows (versorgingsplig). He arrives at the conclusion that the paradox of resentment, instead of gratitude, following (imposed) determination and caring, leads to feelings of hopelessness regarding the future, and this in turn may result in extended suicide, or familicide. 
Du Toit (1988) poignantly describes the psychological state of an oppressive society under siege. He proposes that with the responsibilities of determination right, a value system develops that results in white South Africans viewing sociopolitical change as the end of the world. In view of this outlook, the following expressions are common. 'If my child has to go to school with a black child, it will be the end of the world. If I have to lie in hospital next to a black patient, my world will collapse' (own translation). Selkin (1976:85) describes this situation as an "unbearable threat to their life situation" and states that people who have lived "stable, constructive lives" may commit murdersuicide under these circumstances. Visser (1990:24) states that violence is the symptom of a person's need for recognition, and familicide may be a desperate way of gaining that recognition. De Jongh van Arkel (1985:141) defines familicide as "behaviour that seeks to resolve an existential crisis". It may be that the familicide offenders seek to resolve the existential crisis that is created with the threat of change in South Africa, by committing 'extended suicide'. As the family murdering parent sees no future for the family (and decides on their behalf to relieve them from this fate), so does the oppressor see no future, other than continued domination. The oppressor then decides that it would be better to die rather than to compromise. This decision to die rather than to compromise, is the essential decision that initially established the relationship between the oppressor and the oppressed. The fear is that, like the familicide offender, the white South African society may be in the process of a prolonged national suicide and murder of their 'wards', black South Africans.

The sociopolitical character of white South Africans may predispose them to familicide, but individual difference (in terms of family relations, stress, economic realities, personality conflicts, etc.) may be the final precipitating factor that pushes people to do this drastic deed.

\section{CONCLUSION}

An attempt was made to describe some of the important characteristics of the familicide offender. It seems that in South Africa this person is most likely to be a white, male Afrikaner Protestant in his thirties. High male proprietariness and a distorted sense of responsibility, as well as a sense of fatalism that may lead to suicidality have been suggested. The difference between familial and non-familial offenders that was reported, indicates that familial offenders seem to appear less disturbed (although a high base-line of psychopathology in the white society may distort this observance). In this regard it was also reported that Afrikaners have higher symptom scores than English whites, which may correspond with higher numbers of Afrikaner familicides. High Social Distance, Conservatism, Anomie and BJW scores, together with high stress, may indicate an isolated, alienated, stressed, symptomatic group that have 
(relatively recently - 1948) moved from an oppressed to being an oppressor group. Fanon (1968) and others warn of the self-perpetuating cycle of violence and oppression due to the internalization of the oppressor by the oppressed. Given the inherent personality and other characteristics of the oppressors, it is postulated that when the oppressors' positions are threatened, they will resort to violence as a response to the threat. This violence may be directed at others, but when this does not seem viable to the oppressor, it may be turned on the self as in suicide, or extended suicide (familicide).

A more positive solution to this crisis would be to find a healthier way to respond to the challenges from the oppressed. If whites can understand the dynamics of the oppressor-oppressed relationship, they may realize that through negotiation and compromise, the oppressed can be liberated, and both may live. Positive images of a 'New South Africa' may counteract feelings of fatalism, anxiety, depression and many of the possible 'causes' of familicide that have been proposed.

\section{BIBLIOGRAPHY}

ALlEN, N.H. 1983. Homicide Followed by Suicide. Los Angeles, 1970-1979. Suicide and LifeAPA Threatening Behavior, 13(3):155-165.

sce

AMERICAN PSYCHIATRIC ASSOCIATION. 1987. Diagnostic and Statistical Manual of Mental Disorders. (3rd ed., rev.) Washington, DC.

BEKKER, J.A. 1986. The Psychology of Unrest: Children of Violence. Weekly Mail :14-15, Oct. 17.

BERMAN, A. 1979. Dyadic Dealh: Murder-Suicide. Suicide and Life Threatening Behavior, 9:15-23.

BULHAN, H A. 1985. Frantz Fanon and the Psychology of Oppression. New York : Plenum

COID, J. 1983. The Epidemiology of Abnormal Homicide and Murder Followed by Suicide. Psychological Medicine, 13:855-860.

CRAPANZANO, V. 1985. Waiting: The Whites of South Africa. New York : Random.

DALY, M., \& WILSON, M. 1988. Evolutionary Social Psychology and Family Homicide. Science, 242(4878):519-424.

DAWES, A. 1985. Politics and Mental Health: The Position of Clinical Psychology in South Africa. South African Joumal of Psychology, 15(2):55-61.

DE JONG VAN ARKEL, T. 1985. Pastoraal-teologiese perspektief op gesinsmoord. Suid-Afrikaanse Tydrkif vir Sirafreg en Kriminologie : 140-148.

DEVASIA, V.V. \& DEVASIA, L. 1984. Victim-Offender Relationship in Female Homicide by Males. Indian Joumal of Social Work, 45(3):317-323.

DOMISSE, J. 1983. The Psychiatry and Psychosocial Pathology of Apartheid, 1948-1982. U.N. Centre Against Apartheid, 13(83):1-22, May.

DUCKITT, J.H. 1985. Prejudice and Neurotic Symptomatology among White South Africans. The Joumal of Psychology, 119(1):1-10.

DU TOIT, S.I. 1988. Die aanvaarding van beskikkingsreg as faktor in gesinsmoord. Paper delivered at Psychiatric Conference of Familicide, Pretoria, July 1988.

DU TOIT, S.I. 1990. Family Violence: Familicide. (In McKendrick, B. \& Hoffmann, W. eds. People and Violence in South Africa : Oxford University Press. p. 288-300.) 
FANON, F. 1968. The Wretched of the Earth. New York: Grove Press.

FISHBAIN, DA. 1986. Suicide Pacts and Homicide. American Joumal of Psychiatry, 143(10):1319-1320. GRASER, R.R. 1987. Family Murder: Some Considerations. SACC, 262-268.

HELMS, J.E. 1990. Black and White Racial Identity: Theory, Research and Practice. New York : Greenwood

HOLINGER, P.C. \& KLEMEN, E.H. 1982. Violent Deaths in the United States, 1900-1975. Social Science and Medicine, 16:1929-1938.

HUMPHREY, J.A. \& PALMER, S. 1980. Stressful Life Events and Criminal Homicide Offender-Victim Relationships. Victimology: An Intemational Joumal, 5(2-4):115-120.

HUMPHREY, JA. \& PALMER, S. 1987. Stressful Life Events and Criminal Homicide. Omega Joumal of Death and Dying, 17(4):299-308.

IGA, M., YAMAMOTO, J., NOGUCHI, T., \& KOSHINAGA, J. 1978. Suicide in Japan. Social Science and Medicine, 12(6A):507-516.

ISHIKAWA, E. 1989. Suicide in Japan: Why "Oyako Shinju" (parent-child suicide). Unpublished manuscript. Boston, MA. : Boston University

KRATCOSKI, P.C. 1988. Families Who Kill. Marriage and Family Review, 12(1-2), 47-70.

LAMBLEY, P. 1980. The Psychology of Apartheid. Athens, GA : The University of Georgia Press.

LESTER, D. 1986. Level of Depression in Nations and their Suicide Rate. Psychological Repons, 58, 930.

LIPMAN, R.S., COVI, L., SHAPIRO, A.K. 1979. The Hopkins Symptom Checklist (HSCL). Joumal of Affective Disorders, 1:9-24.

MARRIOTT, C., \& FITZGERALD, J.M. 1981. Nixon's Resignation and Death Rates: Individual/System Interaction in America. Omega Joumal of Death and Dying, 12(2):107-115.

McCULLY, R.S. 1978. The Laugh of Satan: A Study of a Familial Murderer. Joumal of Personality Assessment, 42(1):81-91.

MOOLMAN, E. 1988. Op die randjie van gesinsmoord. Huisgenoot : 10-11, Oktober.

OLIVIER, L. 1988. Family Murder as a Socio-Psychological Phenomenon in the Republic of South Africa. South African Joumal of Sociology, 19(3):117-119.

OLIVIER, L., HAASBROEK, C.P., BEYERS, D., DE JONGH VAN ARKEL, J.T., MARCHETTI, M.C., ROOS, J.L., SCHURINK, E.M., SCHURINK, W.J. \& VISSER, M.J. 1991. The Phenomenon of Family Murder in South Africa: An Exploratory Study. Pretoria : HSRC

PALMER, S., \& HUMPHREY, J.A. 1980. Offender-Victim Relationships in Criminal Homicide Followed by Offender's Suicide. Suicide and Life Threatening Behavior, 10(2):106-118.

PECK, D.L. 1980. Towards a Theory of Suicide: The Case for Modern Fatalism. Onega Joumal of Death and Dying, 11(1):1-14.

PERDUE, W.C. \& LESTER, D. 1973. Those who Murder Kin. Perceptual and Motor Skills, 36(20):606. PETERSON, SA. 1985. Death Anxiely and Politics. Omega Joumal of Death and Dying 16(2):169-174.

PIENAAR, P. 1978. Gesinsmoorde: 'n Kommerwekkende neiging. Woord en Daad, 18:16-18.

PRETORIUS, R. 1987. Gesinsmoord in die Republick van Suid-Afrika: 'n Misplaaste sin van verantwoordelikheid. Suid-Afrikaanse Tydskrif vir Strafreg en Kriminologie :135-141

PRETORIUS, J.W. 1989a. White South African Identity Development and Psychopathology. Unpublished doctoral dissertation. Boston : Boston University.

PRETORIUS, J.W. 1989b. Family Murder in South Africa. Unpublished manuscript. Boston : Boston University.

PRETORIUS, J.W. 1991. Cross-Cultural Research in South Africa: Barriers, Procedures and Findings. Paper delivered at the Winter Roundtable on Cross-Cultural Counseling and Psychotherapy. Columbia University, Teachers College, New York, NY.

ROOS, J.L., HAASBROEK, C.P. \& MARCHETTI, M.C. 1992. Family Murder in a Black South African Family: A Case Report. Geneeskunde, September, 31-35.

ROSENBAUM, M. 1990. The Role of Depression in Couples Involved in Murder-Suicide and Homicide American Joumal of Psychiatry, 147(8): 1036-1039.

SEEDAT, A. 1984. Crippling a Nation. London : International Defense and Aid Fund. 
SELKIN, J. 1976. Rescue Fantasies in Homicide-Suicide. Suicide and Life-Threatening Behavior, 6:79-85. STANDER, K. 1988. Father Power Gets Blame for Murders. Weekend Angus: 5, Sept. 17.

VAN DER SPUY, H.I.J., \& SHAMLEY, D. eds. 1978. The Psychology of Apartheid. Washington : University Press of America.

VISSER, E. 1990. Gesinsmoord. Unisa Psychologia, 17(2): 19-26. 
